\title{
The Effect of Learning Strategy and Writing Motivation on the Ability to Write Short Texts during Covid-19 Pandemic
}

\author{
Arif Yuandana Sinaga ', Nova Erawati Sidabalok 2 \\ DOI: $10.35445 /$ alishlah.v13i3.983
}

\begin{abstract}
Article Info
Abstract

Keywords: Learning strategies, Writing, Short Text

This study aims to determine differences in writing short stories between students taught with Learning Strategies for Improving Thinking Skills (SPPKB) and expository learning strategies. It also determines differences in students' short story writing abilities in online learning students with high and low writing motivation. It also determines the interaction between learning strategies and writing motivation in influencing writing short stories in online learning Diponegoro High School, Asahan Regency. This research was carried out at Diponegoro Senior High School, Asahan Regency, whose research population was tenth grade. This research is quantitative research using quasiexperimental research methods. The research design used was a Randomized Control Group Pretest-Postest Design. The instruments used are treatment instruments in the syllabus, lesson plans, questionnaires, and measurement instruments in short story texts. The study results indicate a difference in the ability to write short stories between the treatment of learning strategies and writing motivation, and there is an interaction in it.
\end{abstract}

\begin{abstract}
Penelitian ini bertujuan untuk mengetahui perbedaan kemampuan menulis cerpen antara siswa yang diajar dengan Strategi Pembelajaran Peningkatan Keterampilan Berpikir (SPPKB) dan strategi pembelajaran ekspositori. Hal ini juga menentukan perbedaan kemampuan menulis cerpen siswa antara siswa yang memiliki motivasi menulis tinggi dan rendah dalam pembelajaran online. Hal ini juga menentukan interaksi antara strategi pembelajaran dan motivasi menulis dalam mempengaruhi menulis cerpen pada pembelajaran online SMA Diponegoro Kabupaten Asahan. Penelitian ini dilaksanakan di SMA Negeri Diponegoro Kabupaten Asahan dengan populasi penelitian adalah siswa kelas XI. Penelitian ini merupakan penelitian kuantitatif dengan menggunakan metode penelitian eksperimen semu. Desain penelitian yang digunakan adalah Rancangan Acak Kelompok Kontrol Pretest-Postest. Instrumen yang digunakan adalah instrumen perlakuan berupa silabus, RPP, angket, dan instrumen pengukuran dalam teks cerpen. Hasil penelitian menunjukkan bahwa terdapat perbedaan kemampuan menulis cerpen antara perlakuan strategi pembelajaran dan motivasi menulis, serta terdapat interaksi di dalamnya.
\end{abstract}

Keywords:

Strategi belajar,

Menulis,

Teks pendek

\footnotetext{
${ }^{1}$ Universitas Efarina, Pematangsiantar, Indonesia

Email: juanda.ariefo8@gmail.com

2 Universitas Efarina, Pematangsiantar, Indonesia

Email: erawatinova@yahoo.co.id
} 


\section{INTRODUCTION}

Due to a lack of preparation, the transition from face-to-face to online presents many challenges (Loviana \& Baskara, 2020). While the COVID-19 pandemic necessitates students to learn online, educators must develop lessons that enhance students' learning abilities (Nurhayati, 2020). Students' motivation, personality, intelligence, and skill levels can all be improved by using effective teaching strategies.

In school, Indonesian language learning is an essential part of the curriculum. Students will be taught to speak, listen, write, and read Indonesian in learning the language. The four language skills are intertwined, so they must all be mastered. This level of language proficiency can only be attained by engaging in regular, sequential activities that begin with listening. Learning to speak comes next, followed by mastery of the written and spoken word. (Alifa, 2020) The ability to write in any of the four major languages, however, is the most difficult to master and the most in-demand (Ranabumi et al., 2017). One of the many factors that determine quality learning, especially when it comes to Indonesian language learning, is the selection of learning strategies (Sinaga and Feranie, 2016). Students should develop creative and critical thinking skills during the learning process if the right learning strategy is used to measure writing ability (Sinaga, 2018).

Thinker's Capacity Enhancement Studying facts and children's experiences can help students develop their critical thinking skills, which helps them develop creative solutions to the challenges they face in school. SPPKB teaches in six stages: orientation, tracking, confrontation, inquiry, accommodation, and transfer. Each stage is followed by a different learning objective (Sanjaya, 2011). Student participation in the learning process benefits SPPKB because it encourages more active and creative thinking in the students, resulting in better long-term retention of information (Sani, 2019). Schools with SPPKB learning, readiness, and mental conditions of teachers and students, which take a long time, have weaknesses (Sanjaya, 2011).

Writing ability is the highest difficulty level to be applied to students (Ranabumi et al., 2017). One factor that makes students less motivated in writing is that writing activities are useless (Troia et al., 2013). This is what underlies researchers to research in the field of writing. The majority of students think that writing activities are useless even though in the era of education 4.0, the government demands that education carried out must have results or outputs, one of which comes from writing activities.

This kind of research was conducted on the learning outcomes of biology subjects in grade 8 (Anisa, Joko, 2013). His research shows that SPPKB can improve students' biology lessons but has constraints in learning time. Another study using SPPKB was also conducted to examine the learning outcomes of PPKn (Kristiyani, 2020). In his research, he explains that the use of SPPKB in Civics learning has higher learning outcomes when compared to conventional strategies. However, SPPKB research that examines Indonesian language learning is rarely found. Although this SPPKB, according to researchers, is very suitable when used in language learning, especially Indonesian, because learning in the context of language demands students to think critically and creatively. Previous research has also been conducted in face-to-face learning and has never been done online. As discussed previously, online learning during the COVID-19 pandemic is a tough challenge for educators due to the lack of motivation to focus and make students passive.

The goal of this study is to examine whether students who were taught using SPPKB and expository learning strategies had different levels of short story writing abilities. Students' ability to write short stories differs between those who have high and low writing motivation in online learning, according to the results. Finally, this research aims to see how students' ability to write short stories in online courses at Diponegoro High School in Asahan Regency is influenced by the interaction between learning strategies and writing motivation. 


\section{METHODS}

Students in class X for the 2020/21 academic year were surveyed as part of this study at Diponegoro High School in Asahan Regency. Learning material in Indonesian subjects taught at Basic Competence number 3.8, which is a comparison of the values and language of folklore (saga) and short stories, and 4.8 , which is developing folklore (saga) into short stories by paying attention to the content and values that exist, are used to select the population.

This study employs a quasi-experimental research design to conduct quantitative research. A Randomized Control Group Pretest-Posttest Design was employed for this study. A variety of treatment and measurement instruments are used, including short story texts assessed on four aspects of content quality, content organization, vocabulary, etiquette, atmosphere exploration, and questionnaires about writing motivation. The instruments are all validated.

Using a stratified cluster random sampling method, this study collected data on participants. A pseudo experimental design was utilized (Quasi-Experimental Research). Using this technique, researchers can see how one variable affects the results of other studies (Sukmadinata, 2016). A treatment (SPPKB) was administered to the experimental group, while no treatment was administered to the control group (SPE) (Sugiono, 2014). A Randomized Control Group PretestPosttest Design was employed for this study. This plan will randomly divide two groups from a population that is either homogenous or aligned (Sukmadinata, 2016). Both groups will be tested with the same test in this design.

Data collection techniques in this study used tests and non-tests. In measuring the ability to write short stories, it is measured using a test technique through students' short stories by looking at four assessment indicators: the quality of the content, the organization of the content, the selection of diction, and the excavation of the atmosphere (Nurgiyantoro, 2004). Meanwhile, in measuring the motivation to write, students will use a non-test technique with a questionnaire containing questions about students' opinions regarding the motivation to write that exists in students and is measured through a Likert scale model. This model provides five answer choices for each question: SS = Strongly Agree, $\mathrm{S}=$ Agree, $\mathrm{KS}=$ Disagree, TS = Disagree, and STS = Strongly Disagree. If students answer SS on a positive question, they will get a score of 5 , and if they answer STS, they will get a score of 1 , and vice versa.

The assessment of the ability to write short stories refers to four aspects of the assessment of short story writing: the quality of the content, the organization of the content, the selection of diction, and the exploration of the atmosphere. For the assessment of each of these aspects will be given a value with the category of very good (SB), good (B), sufficient (C), and less (K). The acquisition of each category is associated with the score that students get from writing short stories, such as in the aspect of content quality, students must get a score of 40 for the very good category (SB), a score of 36 for the good category (B), a score of 30 for the moderate category (C). ) and a score of 28 for the poor category (K). In the aspect of content organization, students must get a score of 30 for the very good category, a score of 26 for the good category, a score of 22 for the moderate category, and a score of 18 for the poor category (Nurgiyantoro, 2013).

The data requirements test in this study goes through four stages: the data normality test, the data homogeneity test, the hypothesis test, and the Tuckey test. The normality test of the data in this study will use the Lilifoer test at a significance level of 0.05. The homogeneity test of the data in this study will use the Bartlett test with a significance level of 0.05. Hypothesis testing in this study will use the two-way ANOVA analysis of variance at a significance level of 0.05. If all the tests show differences and interactions between cells in the factorial design, the test that needs to be done is the Tuckey test. This test aims to compare significantly better results in all related cells in a factorial design (Arikunto, 2019). 


\section{FINDINGS AND DISCUSSION}

In carrying out the research, it was seen that several students in the two classes that were sampled were very interested in participating in this activity, and some students were less interested. This can be seen in the implementation of student learning, who gave responses and questions to no more than 10 students from each class, totaling 32 students. This was confirmed directly by the teacher who taught Indonesian subjects in the sample class, who said that the lack of student motivation was due to online learning. It's just that in the sample class, there is a very visible comparison of student enthusiasm in learning between students who are taught by SPPKB and students who SPE teaches. Classes taught with SPPKB show that there are some students who, without having to be named, directly provide responses and questions to the material presented and other students, even though they have to be asked to provide responses or questions, they can still provide responses or questions that are by the learning material. This is in contrast to the class taught by SPE, which shows that there are students who provide responses and questions without being named but for some students who the researcher mentions by name to provide questions and their responses are confused and unable to give appropriate responses or questions. This indicates that some students who are taught with SPE are not focused on participating in learning. This is in contrast to the class taught by SPE, which shows that there are students who provide responses and questions without being named but for some students who the researcher mentions by name to provide questions and their responses are confused and unable to give appropriate responses or questions. This indicates that some students taught with SPE are not focused on participating in learning. This is in contrast to the class taught by SPE, which shows that there are students who provide responses and questions without being named but for some students who the researcher mentions by name to provide questions and their responses are confused and unable to give appropriate responses or questions. This indicates that some students who are taught with SPE are not focused on participating in learning

The following will describe the description of the value of the short story text of students in the class given the Learning Strategy for Increasing Thinking Ability (Experimental Class) and Expository Learning Strategy (Control Class) and associated with the results of calculating the level of students' writing motivation which has been given through a questionnaire by the design Factorial $2 \times 2$.

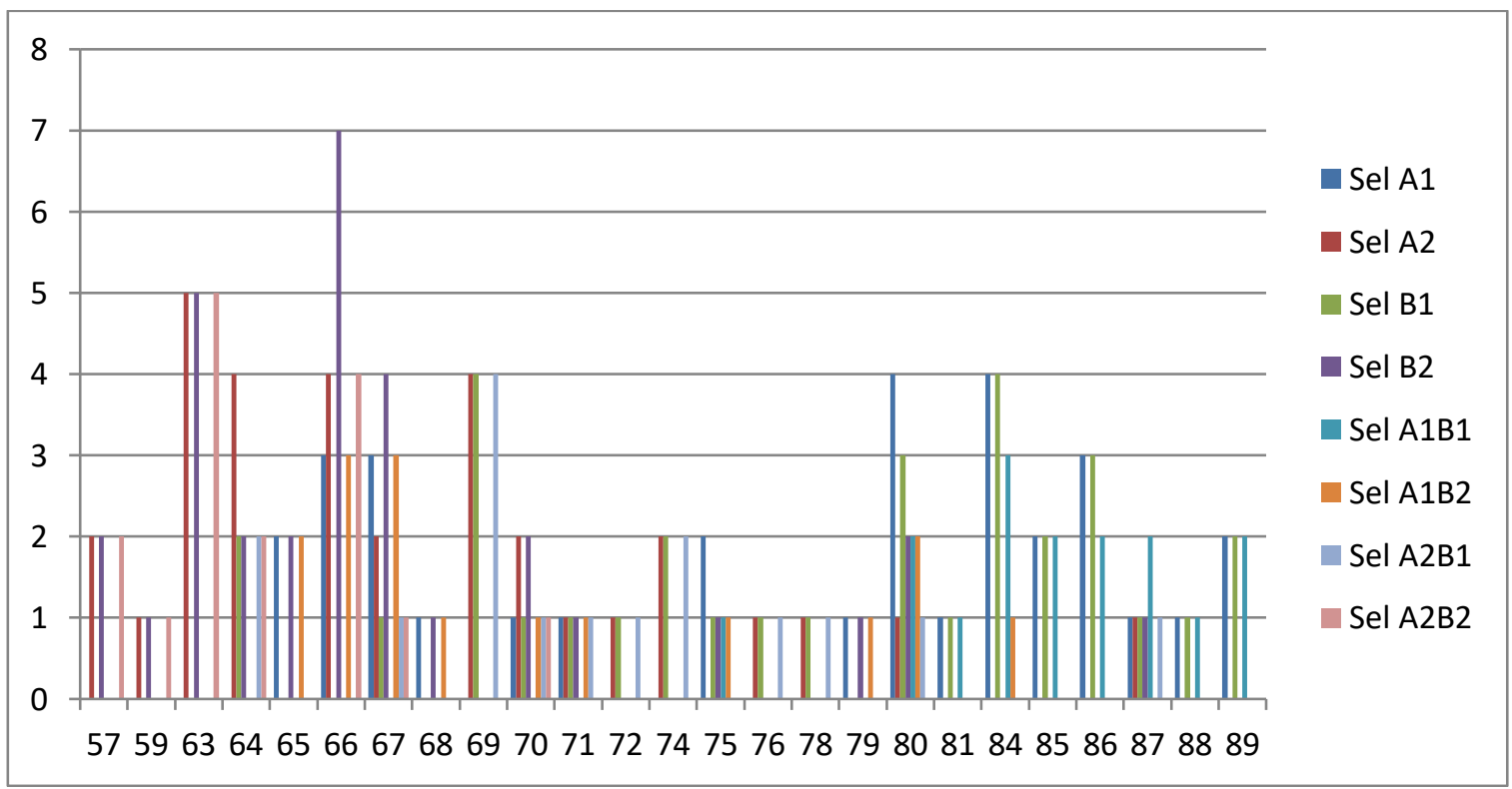

Figure 1. Description of Values in Each Cell of Factorial Design 
Cell A1 : the value of students taught with SPPKB

Cell A2 : the value of students taught with SPE

Cell B1 : the value of students who have high writing motivation

Cell B2 : the value of students who have low writing motivation

Cell A1B1: the value of students who are taught with SPPKB and have high writing motivation

Cell A1B2: the value of students who are taught with SPPKB and have low writing motivation

A2B1 . cell: the value of students who are taught with SPE and have high writing motivation

S2B2 . cells: the value of students who are taught with SPE and have low writing motivation

SPPKB students taught with expository learning strategies will have their scores tested in order to see if there is a difference in their ability to write short stories, and students with high and low writing motivation in online learning will also be tested to see if the two factors interact in their writing abilities. Short story writing at Diponegoro High School, Asahan Regency, via online learning.

\section{Test Data Analysis Requirements}

The data that has been obtained are arranged according to the cells in the $2 \times 2$ factorial design and will go through several tests before entering the hypothesis test, namely the data normality test and the data homogeneity test. In the following, the researcher will describe the results of the calculations through the Excel application.

\section{Normality test}

Utilizing the Liliefors test, a normality test was used to identify any discrepancies in the study's data. Cell A1 (cell A1B2 (scores of the ability to write short stories of Diponegoro high school students who are taught with learning strategies to improve thinking skills for groups of Diponegoro high school students who have low writing motivation), cell A2B1 (scores of ability to write short stories of Diponegoro high school students who are taught by expository learning strategies for groups Diponegoro High School students who have low writing motivation) (the value of the ability to write short stories for Diponegoro High School students who are taught expository learning strategies for groups of Diponegoro High School students who have low writing motivation).

The following table explains the calculations. "Cell A2B1" (measures of students' ability to write short stories) and "Cell A2B2" (scores of ability to write short stories of Diponegoro high school students who are taught by expository learning strategies for groups of students Diponegoro High School which has low writing motivation). The following table provides a more detailed explanation of the calculations. Students in Diponegoro High School who are taught with expository learning strategies for groups of Diponegoro High School students with high writing motivation are shown in cell A2B1 and cell A2B2 (scores of ability to write short stories) (scores of ability to write short stories of Diponegoro high school students who are taught by expository learning strategies for groups of students Diponegoro High School which has low writing motivation). The following table explains the calculations in greater detail.

Table 3. Description of Data Normality Test

\begin{tabular}{|c|c|c|c|c|c|c|c|c|}
\hline Cell & A1 & A2 & B1 & B2 & A1B1 & A1B2 & A2B1 & A2B2 \\
\hline Sample $(n)$ & 32 & 32 & 32 & 32 & 16 & 16 & 16 & 16 \\
\hline Highest Score & 89 & 87 & 89 & 84 & 89 & 84 & 87 & 70 \\
\hline Lowest Score & 65 & 57 & 64 & 57 & 75 & 65 & 64 & 57 \\
\hline mean & 77,65 & 67,81 & 78,09 & 67,28 & 84,37 & 71 & 72,06 & 63,56 \\
\hline Standard Deviation & 8,5 & 6,49 & 7,84 & 6,33 & 3,77 & 6,408 & 6,016 & 3,520 \\
\hline Variance & 72,36 & 42,15 & 61,57 & 40,14 & 14,25 & 41,06 & 36,19 & 12,39 \\
\hline L Count (Lo) & 0,1454 & 0,1270 & 0,1484 & 01336 & 0,151 & 0,192 & 0,208 & 0,120 \\
\hline L Table o,o5 (Lt) & 0,1562 & 0,1562 & 0,1562 & 0,1562 & 0,2130 & 0,2130 & 0,2130 & 0,2130 \\
\hline Category & Normal & Normal & Normal & Normal & Normal & Normal & Normal & Normal \\
\hline
\end{tabular}


In accordance with the description of the calculation of the data analysis test above, it is known that the overall data is in the calculated $\mathrm{L}$ value (Lo) must be smaller than the table $\mathrm{L}$ (Lt) so that the data in all cells is classified as normal.

\section{Homogeneity Test}

The homogeneity test in this study aims to determine the equivalence of the ability to write short stories of Diponegoro High School students based on the cells in the 2x2 factorial design, namely cells $\mathrm{A} 1 \mathrm{~B} 1, \mathrm{~A} 1 \mathrm{~B} 2, \mathrm{~A} 2 \mathrm{~B} 1$, and $\mathrm{A} 2 \mathrm{~B} 2$. This homogeneity test uses the Bartlett test at a significant level of $=0.05$ to test $\mathrm{Ho}$, which states that the variance of the ability to write short stories based on factorial cells is homogeneous. If $\mathrm{Ho}$ is rejected, then $\mathrm{H} 1$ is accepted with the statement that the variance of the ability to write short stories based on factorial cells is not homogeneous. The criteria for this test are that Ho is rejected and $\mathrm{H} 1$ is accepted if the value of the chi squared calculation is smaller than the value of the chi square table which in this study is 9.48. For further explanation of calculations will be described through the following table.

Table 4. Description of Data Homogeneity Test

\begin{tabular}{ccccccccc}
\hline SAMPLE & Variant S2 & db S2 & S2 Logs & db log S2 & $\begin{array}{c}\text { Combined } \\
\text { Var }\end{array}$ & $\begin{array}{c}\text { Bartle } \\
\text { tt } \\
\text { Value }\end{array}$ & $\begin{array}{c}\text { Chi } \\
\text { Square } \\
\text { Count }\end{array}$ & $\begin{array}{c}\text { Chi } \\
\text { Square } \\
\text { Count }\end{array}$ \\
\hline 1(A1B1) & 14,25 & 213,75 & 1,15 & 17,30 & & & & \\
2(A1B2) & 41,06 & 616 & 1,61 & 24,20 & & & \\
3(A2B1) & 36,19 & 542,93 & 1,55 & 23,37 & 1,41 & 84,87 & 8,24 & 9,48 \\
4(A2B2) & 12,39 & 185,93 & 1,09 & 16,39 & & & \\
total & 103,90 & 1558,62 & 5,41 & 81,28 & & & \\
\hline
\end{tabular}

After calculating the data, it is known that the chi-squared value in this data is 8.24 while the chi table value is 9.48 . The criteria for testing this data are that the calculated chi-squared value must be smaller than the table chi-square based on these results. This data is homogeneous.

\section{Hypothesis testing}

To determine whether the null hypothesis (Ho) is accepted, the research data through the normality and homogeneity test must be tested using the Two Way Variant (ANOVA) data analysis technique. Suppose the results of the data calculations show that there are differences. In that case, the hypothesis test will be continued with the Tuckey test to see an interaction between the research variables. The Tuckey test formula is = with test criteria $\mathrm{F}$ count (Fh) must be greater than $\mathrm{F}$ Table (Ft) $\frac{\left(X_{t}^{-}-X_{j}^{-}\right.}{\sqrt{\frac{R J K D}{n}}}$ (Arikunto, 2019).

The following will describe the results of the calculation of the data hypothesis test through table 5 .

Table 5. Description of Data for Hypothesis Testing

\begin{tabular}{|c|c|c|c|c|c|c|}
\hline All Variance & Db & $\mathbf{J k}$ & $\mathbf{R J K}=\mathrm{JK} / \mathrm{db}$ & Fh $=$ RK/RKD & Ft & \\
\hline $\mathrm{AK}$ & 1 & 1550,3906 & 1550,3906 & 59,68301 & 4 & 4 received \\
\hline $\mathrm{AB}$ & 1 & 2059,5469 & 2059,5469 & 79,28322 & 4 & 4 received \\
\hline I & 1 & 104,92188 & 104,92188 & 4,039017 & 4 & 4 received \\
\hline DK & 60 & 1558,625 & 25,977083 & & & \\
\hline $\mathrm{T}$ & 63 & 5273,4844 & & & & \\
\hline
\end{tabular}

The first hypothesis is accepted because the F count in the first cell is greater than the F table, which means that students taught with SPPKB and expository learning strategies in online learning have different writing abilities. Since F arithmetic is greater than the F table in the second cell, it is safe to assume that the second hypothesis is correct. Students with high and low levels of writing motivation differ in their ability to write short stories. For example, the calculated $\mathrm{F}$ in the third cell is greater than the $\mathrm{F}$ table, so the third hypothesis is accepted; namely, there is an interaction 
between learning strategies and writing motivation in online learning at Diponegoro High School Asahan Regency.

Because the above calculation results show differences between cells (high writing motivation and low writing motivation) in influencing the ability to write short stories, it is necessary to carry out further tests using the Tuckey test. This test was conducted to determine which short story writing skills were the best between classes that received different learning strategies (SPPKB and SPE) and students' writing motivation. This test also meets the requirements if the two research classes have the same samples. In this study, the two classes each have 32 students. table 6.

After doing the calculations, the researchers will describe the results of the Tuckey test in

Table 6. Description of the Tukcey Test

\begin{tabular}{|c|c|c|c|c|c|c|c|c|}
\hline Aspect & Class & $\begin{array}{l}\text { Motivatio } \\
\text { n }\end{array}$ & Class A1 & $\begin{array}{l}\text { Class } \\
\text { A2 }\end{array}$ & $\begin{array}{l}\text { Motivation } \\
\text { B1 }\end{array}$ & $\begin{array}{l}\text { Motivation } \\
\text { B2 }\end{array}$ & & \\
\hline $\mathbf{X 1}$ & A1 & B1 & $\mathrm{A} 1 \mathrm{~B} 1$ & $\mathrm{~A} 2 \mathrm{~B} 1$ & $\mathrm{~A} 1 \mathrm{~B} 1$ & $\mathrm{~A} 1 \mathrm{~B} 2$ & A1B1 & $\mathrm{A} 1 \mathrm{~B} 2$ \\
\hline $\mathbf{X} 2$ & A2 & B2 & $\mathrm{A} 1 \mathrm{~B} 2$ & $\mathrm{~A} 2 \mathrm{~B} 2$ & $\mathrm{~A} 2 \mathrm{~B} 1$ & $\mathrm{~A} 2 \mathrm{~B} 2$ & $\mathrm{~A} 2 \mathrm{~B} 2$ & $\mathrm{~A} 2 \mathrm{~B} 1$ \\
\hline Mean 1 & 77,65 & 78,09 & 84,37 & 72,06 & 84,37 & 71 & 84,37 & 71 \\
\hline Mean 2 & 67,81 & 67,28 & 71 & 63,56 & 72,06 & 63,56 & 63,56 & 72,06 \\
\hline $\mathbf{N}$ & 32 & 32 & 16 & 16 & 16 & 16 & 16 & 16 \\
\hline $\begin{array}{l}\text { Mean } 1 \\
\text { Kean } 2\end{array}$ & $\begin{array}{r}9,84 \\
-\quad\end{array}$ & 10,81 & 13,37 & 8,5 & 12,31 & 7,43 & 20,81 & $-1,06$ \\
\hline$\sqrt{R J K D / n}$ & 0,89 & 0,89 & 1,29 & 1,29 & 1,29 & 1,29 & 1,29 & 1,29 \\
\hline $\begin{array}{l}\text { Q Hitung } \\
\text { Q tabel }\end{array}$ & $\begin{array}{l}11,04 \\
2,88 \\
\text { sign }\end{array}$ & $\begin{array}{l}12,13 \\
2,88 \\
\text { sign }\end{array}$ & $\begin{array}{l}10,36 \\
3 \\
\text { sign }\end{array}$ & $\begin{array}{l}6,58 \\
3 \\
\text { sign }\end{array}$ & $\begin{array}{l}9,54 \\
3 \\
\text { sign }\end{array}$ & $\begin{array}{l}5,76 \\
3 \\
\text { sign }\end{array}$ & $\begin{array}{l}16,13 \\
3 \\
\text { sign }\end{array}$ & $\begin{array}{l}-0,82 \\
3 \\
\text { not sign }\end{array}$ \\
\hline
\end{tabular}

With $\mathrm{n}=32$ and $\mathrm{db}=2$, we get a $\mathrm{Q}$ count of 11.04 and a $\mathrm{Q}$ table of 2.88 at a significance level of 0.05 using the data described above. This indicates that students in Diponegoro high school who were taught learning strategies to increase thinking skills were better at writing short stories than students in Diponegoro high school who were taught by expository learning strategies in online learning.

To put it another way, students who have a high level of writing motivation outperform those who have a low level of writing motivation in online learning when it comes to their ability to write short stories. Students who are taught with learning strategies to improve thinking skills in Diponegoro High School students with high writing motivation have better short story writing skills than students who are taught with learning strategies to improve thinking skills students with low writing motivation. To put it another way, Diponegoro high school students who were taught using expository learning strategies and had high levels of writing motivation had their ability to write short stories rated higher than students who were taught using the opposite strategy and had low levels of writing motivation.

There is a significant difference in the value of short story writing skills between students who are taught with expository learning strategies and students who are taught with learning strategies to increase thinking skills for those who have high writing motivation. This means that students with low writing motivation use learning strategies to increase thinking skills more effectively than students taught expository learning strategies when writing short stories in the sixth row, where Q count is greater than the Q table. Students at Diponegoro High School are grouped into high and low writing motivation groups. The selection of the right learning strategy has a significant impact on the differences in students' learning strategies and their ability to write short stories. There is a significant difference in the value of short story writing skills between students at Diponegoro High School who are taught with learning strategies to improve their thinking skills and students who are taught with expository learning strategies.

Based on the discussion above, the research results obtained are not much different from the research that researchers have done before. Research conducted that used SPPKB in learning 
Indonesian also found that students who were motivated to write and taught using SPPKB had higher average scores than other groups (Sinaga, 2018). To increase students' writing motivation, creative ways are needed to start learning, from teaching methods to learning media. The selection of the right teaching methods and learning media can increase students' self-motivation by themselves. In the learning process, the teacher does not need to regulate students because of the enthusiasm that is so great (Juliati, 2014). Teaching methods that can generate imaginative power in students improve short story writing skills by developing creative thinking(Ernalinda, 2015). SPPKB is a learning strategy that increases children's imaginative power because it is empirical and answers problems from the student's own experience. The results of learning using expository strategies in this study are seen below, with learning outcomes using SPPKB. This shows that the expository strategy is not suitable for non-exact learning but is very suitable when used in exact learning such as physics subjects (Afnan, 2018).

\section{CONCLUSION}

Learning strategies and writing motivation play a role in learning, especially in online learning, according to research done with data that has gone through various stages of testing requirements analysis and testing hypotheses. For students who are taught with SPPKB, both students with high and low levels of writing motivation, the value is higher than for students who are taught SPE. As a result, SPPKB encourages students to think critically, be imaginative, and be enthusiastic about their studies. Online learning media, such as unreliable signals, a hostile learning environment, and students' motivation, were all obstacles in the study. Even if the strategy or media used in online learning is excellent, researchers believe face-to-face learning will always be better. Because of this, the researcher recommends ensuring students' internet signals or helping to provide a stable internet quota for other researchers interested in online learning research. Online learning should run smoothly and provide some comfort in approaching teaching and learning activities faceto-face.

\section{REFERENCES}

Afnan. (2018). Application of Expository Learning Strategies to Improve Physics Learning Outcomes. Madania, 8(1), 32.

Alifa, N. (2020). The Effect Of Short Story Listening And Reading Skills On Short Text Writing Skills. Journal of Indonesian Language and Literature Education, 9(2), 6. file://C:/Users/User/Downloads/39634-Article Text-127871-1-10-20210519.pdf

Anisa, Joko, S. (2013). The Effectiveness Of The Thinking Ability Learning Strategy (Sppkb) On Learning Outcomes And Student Activities Using The Synergetic Teaching Strategy (In Biology Lessons At SMP Negeri 10 Jember). Radiance, 2(4), 11.

Arikunto. (2019). Research Methodology, An Introduction to Education. In Rineka Cipta, Jakarta.

Ernalinda. (2015). The Influence of the Constructive Mind Mapping Model on the Ability to Write Short Stories at SMA Negeri 19 Palembang. Slang, 2(2), 8.

Juliati, AD (2014). Increasing The Motivation Of Writing Children Aged 5-6 Years Through The Use Of Comic Media. Scientific Journal of VISION P2TK PAUDNI, 9(2), 7.

Kristiyani, N. (2020). The Influence of Thinking Ability Improvement Learning Strategy (SPPKB) on Critical Thinking Skills and Social Studies Learning Outcomes. Indonesian Social Studies Education Journal, 4(2), 53. https://doi.org/10.23887/pips/v4i2.3379

Loviana, S., \& Baskara, WN (2020). The impact of the covid-19 pandemic on the readiness of IAIN Metro Lampung tadris mathematics learning. Epsilon.

Nurgiyantoro, B. (2004). Competency-Based Literature Learning Assessment. Diction.

Nurgiyantoro, B. (2013). Evaluation of Indonesian Language Teaching. BPFE.

Nurhayati, E. (2020). Increase student activity in online learning through the Quiziz educational game media during the prevention of the spread of Covid-19. Journal of Pedagogy.

Ranabumi, R., Rohmadi, M., \& Subiyantoro, S. (2017). Improving Students' Writing Short Story Skill 
through Time Token Learning and Video Media. Journal of Education and Learning (EduLearn). https://doi.org/10.11591/edulearn.v11i4.6808

Sani, RA (2019). Learning innovation (5th ed.). Earth Literature.

Sanjaya, W. (2011). Educational Process Standard Oriented Learning Strategy. Kencana Prenada Media.

Sinaga, A. (2018). The Effect Of Learning Strategy On Short Story Writing Ability In Class Xi Students Of SMA N 5 Surakarta. STKIP PGRI Grammar of West Sumatra. https://doi.org/10.22202/jg.2018.v4i1.2452

Sinaga and Feranie. (2016). Enhancing Critical Thinking Skills and Writing Skills through the Variation in Non_Traditional Writing Task. International Journal of Instruction, 10(2), 70. https://doi.org/1308-1470

Troia, GA, Harbaugh, AG, Shankland, RK, Wolbers, KA, \& Lawrence, AM (2013). Relationships between writing motivation, writing activity, and writing performance: Effects of grade, sex, and ability. Reading and Writing. https://doi.org/10.1007/s11145-012-9379-2 